\title{
Is The Thoracolumbar Injury Severity Score (TLISS) Still A Good Base For The Education Of Residents In Orthopaedics And Traumatology
}

\begin{abstract}
Introduction. Thoracolumbar spinal injuries indicated for surgical intervention specify the necessity of intervention within 24 hours. The traumatologists working in a structure without a Spinal Unit must be able to evaluate such injury and set indications for surgical treatment, that is, nonoperative treatment. The purpose of this study is to evaluate if Thoracolumbar Injury Severity Score (TLISS) is still a good base for the classification of thoracolumbar spinal injuries and to give a correct indication for nonoperative, that is, surgical treatment.
\end{abstract}

Patients and Methods. Six Orthopaedics and Traumatology residents from Siena (Italy), five Orthopaedics and Traumatology residents from the Clinical Centre of Banja Luka (Bosnia and Herzegovina) and five Orthopaedics and Traumatology residents from the Alta Val d'Elsa Hospital, Siena (Italy) were presented 24 clinical cases from professional literature where the following data were indicated: patient's age, neurological conditions, description of the injury, mechanism of the injury and radiological findings (RTG, MR). The abovementioned 24 patients were chosen from the literature based on the injuries mostly seen by an orthopaedist with a lack of experience in the problems of spinal column trauma (low energy trauma, with partial or without neurological impairments, with the TLISS score of 4). The residents from the three groups had to classify all patients according to the TLISS score and to define the most appropriate method of treatmentconservative or surgical, and after that, all classifications, as well as the therapeutic decisions, were compared. The statistical methods used in this study include: statistical significance, reliability $(\mathrm{P}<0.05)$, the validity of the decision, the percentage of accuracy and Cohen's kappa coefficient.

The best results in evaluation of the mechanism of the injury were demonstrated by the group of doctors from the Orthopaedic Hospital with an accuracy of 78.8\% $(P<0.05)$ and with an average correlation $(K=0.598)$. The best description of the injury was presented by the doctors from Siena with $87 \%$ accuracy $(P<0.05)$ and with correlation $(K=0.749)$. The doctors from Siena responded best at evaluating the neurological status with $97.6 \%$ accuracy $(\mathrm{P}<0.05)$ and with correlation $(\mathrm{K}=0.936)$. The assessment of the injury of the $P C L$ residents from Siena was $64.7 \%$ accurate $(P<0.05)$ with correlation $(K=0.426)$. The total TLISS score was best calculated by the residents of Siena with $82 \%$ accuracy $(\mathrm{P}<0.05)$ and correlation $(\mathrm{K}=0.718)$. The most appropriate therapeutic decision was made by the residents from Siena with $80.3 \%$ accuracy $(P<0.05)$ and with correlation $(K=0.707)$.

Conclusion. Currently, the Denis classification and the AO classification are the most widely used classification algorithms for the fractures of thoracolumbar spine but some defects have also been identified in both of them. The value of TLISS evaluation is by the three groups of residents in presented 24 patients from the professional literature. Significant differences in accuracy were found in defining a real damage of the spinal cord at the level of the cauda equina. The evaluation of the integrity of the posterior longitudinal ligament by the radiography is of low accuracy.

Key Words: spine fractures, thoracolumbar spine, TLISS, education.
Luigi Meccariello', Serafino Carta, Mattia Fortina ${ }^{1}$, Milorad Maran', Marco Mugnaini, ${ }^{3}$, Francesco Vitaliano Muzī̌ ${ }^{4}$, Paolo Ferrata ${ }^{1}$

${ }^{1}$ Department of Human Pathology and Oncology, Division of Orthopedics and Traumatology, University of Siena, Italy

${ }^{2}$ Traumatology Clinic, Clinical Centre Banja Luka, Republic of Srpska, Bosnia and Herzegovina ${ }^{3}$ Operative Unit of Orthopedics and Traumatology, Alta Val d'Elsa Hospital, Poggibonsi, Siena, Italy ${ }^{4}$ Department of Neurological Sciences, Neurosurgery and Behavior, Division of Neurosurgery, University of Siena, Italy

\section{Contact address:}

Luigi Meccariello, $M D$

University of Siena

University Hospital

"Santa Maria alle Scotte"

Viale Bracci 1,

53100 Siena, Italy. email:drlordmec@gmail.com

Tel: +390577585675

Cell: +393299419574 . 


\section{Introduction}

One of the proven facts in medicine, based on the evidences (EBM), is that the patients with the thoracolumbar spine injury, if the injury is indicated for the surgical treatment, should be given a surgical intervention and the fracture must be stabilized within 24 hours after the injury. It is up to the orthopaedists and traumatologists working in the institutions without a spine surgeon or a surgeon dealing with the spinal column injuries to decide whether a patient should be directed for a nonoperative or operative treatment. For that reason, the orthopaedists must have a broad theoretical knowledge regarding the injuries of the spinal column. In an attempt to reduce the variability and improve the result in evaluation and indications for the treatment of such injuries, Vaccaro and his co-workers showed in their study that, even though there are other classifications in use, the TLISS (Thoracolumbar Injury Severity Score) still presents a good reference for the medicine and specialist education of the orthopaedists and traumatologists. The aim of this study is to evaluate if the TLISS classification is an adequate classification when it comes to the thoracolumbar spinal injuries, as well as to determine if it is still a good base for the education of orthopaedists and traumatologists.

\section{Patients and Methods}

Six residents in Orthopaedics and Traumatology from the Polyclinic "Santa Maria alle Scotte" were given the material with the following topics: anatomy and biomechanics of the spinal column, classification of the thoracolumbar fractures, classification of thoracolumbar spine fractures TLISS, neurological outcome of the operative and nonoperative treatment of spinal column injuries. The same material was also distributed to the 5 residents in Orthopaedics and Traumatology at the Clinical Centre Banja Luka, Bosnia and Herzegovina, while the 5 residents in Orthopaedics and Traumatology from the Orthopaedic Hospital Alta Val d'Elsa were only given the works explaining what TLISS is. This classification was chosen because, among other things, it considers the mechanism of the injury, otfen not included in an anamnesis taken by a surgeon. In our work we introduced residents with 24 clinical cases published in PubMed and professional journals specialized in spinal column, etc. Even though our Institution has the Center for Spinal Surgery within its own structures, we didn't have a sufficient number of patients for this study. The following were taken into consideration: patient's age, neurological status and the description of the mechanism of injury. All patients were shown on standard radiographies in two projections, as well as on CT and MR in the sagittal projection in T2 sequence. The abovementioned 24 patients were chosen from the literature based on the criteria of injuries mainly seen by an orthopaedist inexperienced in problems of spinal column trauma (low energy trauma, with partial or without neurological impairments, with the TLISS score of 4). The residents from the three groups had to classify all patients according to the TLISS score and to define the most appropriate method of treatment-conservative or surgical, and after that, all classifications, as well as the therapeutic decisions, were compared among the groups of doctors mentioned .

Thoracolumbar spine injury classification TLISS objectifies the factors leading to the injuries and helps a spinal surgeon in choosing the most adequate treatment. The TLISS is based on three major factors of the thoracolumbar trauma: injury and the mechanism of injury, the integrity of the posterior longitudinal ligament (CLP) and patient's neurological status. The mechanism of injury and integrity of CLP are deduced from the observations of imaging studies including radiographies and / or MR of the thoracolumbar spine. Based on the scoring within these three factors, a total score is being calculated and it can be used to define an adequate therapy. Possible mechanisms of injury include compression, rotation and distraction. One to four points are awarded based on the mechanism of injury.

Patients with normal neurological status are given o points. Patients with an injury to the nerve root or a lesion of the spinal cord or cauda equina syndrome are awarded 1 to 3 points and these patients can benefit from surgical decompression.

The third major component of the TLISS algorithm also includes the assessment of the integrity of the posterior longitudinal ligament (CLP). The integrity of the CLP is determined by clinical examination and radiographies and / or by the CT and MR images (interspinal gap). Patient with an intact CLP is given o points. If a ligament is injured 3 points are awarded and if the status of the CLP is indeterminate 2 points are assigned.

The total score in the TLISS evaluation system evaluates the severity of the trauma and helps guide the decision between two choices: nonoperative or operative therapy.

Patients with a score less than or equal to 3 are indicated for the nonoperative treatment, while patients with a score greater than or equal to 5 are indicated for the surgical treatment, performed by the stabilization of fractures, with or without decompression. Patients with a total score of 4 fall in the category of the intermediates and the choice of therapy rests on the experience of the surgeon. The percentage of reliability of the evaluation system TLISS has been shown to be significant (the values of $\mathrm{K}$ are between $0.24-0.724$ ). Recent studies prove a high reliability rate. 
Table 1: TLISS algorithm

\begin{tabular}{lcc}
\hline & Qualification & Points \\
\hline --Mechanism of injury & - & \\
\hline Compressional & Lateral angulation & 1 \\
\hline & $>15^{\circ}$ & 1 \\
\hline & Burst & 1 \\
\hline Translational/rotational & - & 3 \\
\hline Distractional & - & 4 \\
\hline II-Neurological status & - & 0 \\
\hline Without impairments & - & 2 \\
\hline Nerve root injury & Incomplete & 3 \\
\hline Spinal cord injury & & \\
(including the conus & & 2 \\
medullaris) & Complete & 3 \\
\hline Cauda equine syndrom & - & 3 \\
\hline III- Integrity of the & - & \\
posterior longitudinal & - & \\
ligament (CLP) & - & \\
\hline Intact & & \\
\hline Suspected injury & - & \\
\hline Injured & & \\
\hline
\end{tabular}

The reliability and validity of the decisions on the method of treatment made by the TLISS system of the residents in Orthopaedics and Traumatology from Siena were compared with those made by the doctors from two control groups: a group of residents in Orthopaedics and Traumatology of the Orthopaedic Hospital from Siena and a group of residents in Orthopaedics and Traumatology of the Clinical Centre Banja Luka (BiH). The results were measured by Cohen's kappa coefficient. The Cohen's kappa coefficient is a measure accepted in the international studies and it quantifies the degree of agreement between observers in order to reduce the subjectivity.

This coefficient is between $\mathrm{o}$ and 1 . o corresponds to an accidental correlation or a complete mismatch in tests, while 1 corresponds to a perfect correlation between the tests.

- from 0.00 to 0.20 : minimal correlation

- from 0.21 to 0.40 : slight correlation

- from 0.41 to 0.60 : medium correlation

- from 0.61 to 0.80 : significant correlation.

- from 0.81 to 1.00: perfect correlation

\section{Results}

Research results are presented in Table 2. The best results in evaluating the mechanism of injury were found in a group of doctors from the Orthopaedic Hospital with the accuracy of $78.8 \%(\mathrm{P}<0.05)$ with an average correlation coefficient $\mathrm{K}=0.598$. The best description of injury was presented by the residents from Siena with the accuracy of $87 \%(\mathrm{P}<0.05)$ and with the correlation coefficient $\mathrm{K}=0.749$. The doctors from Siena gave the best assesment of the neurological status with the accuracy of $97.6 \%(\mathrm{P}<0.05)$, with the correlation coefficient $\mathrm{K}=0.936$. The assessment of the injury of PCL of the residents from Siena showed the accuracy of $64.7 \%(\mathrm{P}<0,05)$, with the correlation coefficient $\mathrm{K}=0.426$. The residents from Siena made the best calculation of the total TLISS score with the accuracy of $82 \%(\mathrm{P}<0,05)$ and with the correlation coefficient $\mathrm{K}=0.718$. The doctors from Siena also had the most adequate choice of therapy with the accuracy of $80.3 \%(\mathrm{P}<0,05)$ and the correlation coefficient $\mathrm{K}=0.707$.

Table 2. Results

\begin{tabular}{|c|c|c|}
\hline & \\
\hline & $\begin{array}{c}\text { Percentage of } \\
\text { accuracy }\end{array}$ & Cohen's Kappa \\
\hline \multicolumn{3}{|l|}{ Mechanism of injury } \\
\hline AOU Siena & 76.1 & 0.580 \\
\hline Orthopaedic Hospital & 78.8 & 0.598 \\
\hline $\begin{array}{l}\text { Clinical Centre Banja } \\
\text { Luka (BiH) } \\
\end{array}$ & 76.5 & 0.583 \\
\hline \multicolumn{3}{|l|}{$\begin{array}{l}\text { Classification of } \\
\text { fractures }\end{array}$} \\
\hline AOU Siena & 74.3 & 0.569 \\
\hline Orthopaedic Hospital & 86.2 & 0.744 \\
\hline \multicolumn{3}{|l|}{$\begin{array}{l}\text { Clinical Centre Banja } \\
\text { Luka }(\mathrm{BiH})\end{array}$} \\
\hline \multicolumn{3}{|l|}{ Neurological status } \\
\hline AOU Siena & $97.6^{*}$ & 0.936 \\
\hline Orthopaedic Hospital & 94.6 & 0.907 \\
\hline $\begin{array}{l}\text { Clinical Centre Banja } \\
\text { Luka }(\mathrm{BiH}) \\
\end{array}$ & 96.9 & 0.911 \\
\hline \multicolumn{3}{|l|}{ Integrity of the CLP } \\
\hline AOU Siena & $67.4^{*}$ & 0.426 \\
\hline Orthopaedic Hospital & 63.4 & 0.400 \\
\hline $\begin{array}{l}\text { Clinical Centre Banja } \\
\text { Luka }(\mathrm{BiH})\end{array}$ & 65.4 & 0.413 \\
\hline \multicolumn{3}{|l|}{ Total TLISS score } \\
\hline AOU Siena & $82.0^{\star}$ & 0.718 \\
\hline Orthopaedic Hospital & 77.8 & 0.581 \\
\hline $\begin{array}{l}\text { Clinical Centre Banja } \\
\text { Luka }(\mathrm{BiH}) \\
\end{array}$ & 81.2 & 0.713 \\
\hline \multicolumn{3}{|l|}{ Choice of treatment } \\
\hline AOU Siena & $80.3^{*}$ & 0.707 \\
\hline Orthopaedic Hospital & 73.7 & 0.562 \\
\hline $\begin{array}{l}\text { Clinical Centre Banja } \\
\text { Luka }(\mathrm{BiH})\end{array}$ & 77.4 & 0.689 \\
\hline
\end{tabular}




\section{Discusion}

The aim of the study was to establish whether a resident in Orthopaedics and Traumatology is able after his/her specialization to choose correctly the methods of treatment of thoracolumbar spine injuries. Empirically, we have discovered that this is a weak spot in their professional training.

Currently, both the Denis and the AO classifications are the most used classification algorithms for the fractures of thoracolumbar spine, but some defects have also been identified in both of them. The value of TLISS evaluation is by the three groups of residents in presented 24 patients from the professional literature.

By analyzing the data, we have received responses of the participants in the questionnaires, where the mechanism of the fracture occurrence was best described by the doctors who are able to understand it better due to their experience.

\section{Conclusion}

The previous study conducted by Vaccaro and his coworkers has already shown that the TLISS classification can be used for a correct diagnosis, as well as when it comes to choosing methods of treating thoracolumbar spine trauma. The most useful, but at the same time the most difficult for the decision, is TLISS $=4$, where the decision on a method of treatment is based on the experience of a surgeon. This study offers encouraging results for the use of TLISS algorithm for the classification of thoracolumbar spine injuries, methods of treatment, as well as for the education of residents in Orthopaedics and Traumatology and surgeons who are not primarily involved in thoracolumbar spine injuries.

It is likely that the Thoracolumbar Injury Classification and Severity Score (TLICS) may be easier to use, but it is something that still needs to be investigated.

\section{References}

1. Vaccaro AR, Lehman RA Jr, Hurlbert RJ, Anderson PA, Harris M, Hedlund R, Harrop J, Dvorak M, Wood K, Fehlings MG, Fisher C, Zeiller SC, Anderson DG, Bono CM, Stock GH, Brown AK, Kuklo T, Oner FC. A new classification of thoracolumbar injuries: the importance of injury morphology, the integrity of the posterior ligamentous complex, and neurologic status.Spine 2005;30:2325-33.

2. Haba H, Taneichi H, Kotani $Y$, Terae S, Abe S, Yoshikawa H, Abumi K, Minami A, Kaneda K.Diagnostic accuracy of magnetic resonance imaging for detecting posterior ligamentous complex injury associated with thoracic and lumbar fractures. J Neurosurg 2003;99:20-6.

3. Vaccaro AR, Zeiller SC, Hulbert RJ, Anderson PA, Harris M, Hedlund R, Harrop J, Dvorak M, Wood K, Fehlings MG, Fisher C, Lehman RA Jr, Anderson DG, Bono CM, Kuklo T, Oner FC.The thoracolumbar injury severity score: a proposed treatment algorithm. J Spinal Disord Tech 2005;18:209-15.

4. Whang PG, Vaccaro AR, Poelstra KA, Patel AA, Anderson DG, Albert TJ, Hilibrand AS, Harrop JS, Sharan AD, Ratliff JK, Hurlbert RJ, Anderson P, Aarabi B, Sekhon LH, Gahr R, Carrino JA.The influence of fracture mechanism and morphology on the reliability and validity of two novel thoracolumbar injury classification systems. Spine 2007;32:791-5.

5. Raja Rampersaud Y, Fisher C, Wilsey J, Arnold P, Anand N, Bono CM, Dailey AT, Dvorak M, Fehlings MG, Harrop JS, Oner FC, Vaccaro AR.Agreement between orthopaedic surgeons and neurosurgeons regarding a new algorithm for the treatment of thoracolumbar injuries: a multicenter reliability study. J Spinal Disord Tech 2006;19:477-82.

6. Patel AA, Vaccaro AR, Albert TJ, Hilibrand AS, Harrop JS, Anderson DG, Sharan A, Whang PG, Poelstra KA, Arnold P, Dimar J, Madrazo I, Hegde S.The adoption of a new classification system: time-dependent variation in interobserver reliability of the thoracolumbar injury severity score classification system. Spine 2007;32:E105-10.

7. Harrop JS, Vaccaro AR, Hurlbert RJ, Wilsey JT, Baron EM, Shaffrey CI, Fisher CG, Dvorak MF, Oner FC, Wood KB, Anand N, Anderson DG, Lim MR, Lee JY, Bono CM, Arnold PM, Rampersaud YR, Fehlings MG; Spine Trauma Study Group.Intrarater and interrater reliability and validity in the assessment of the mechanism of injury and integrity of the posterior ligamentous complex: a novel injury severity scoring system for thoracolumbar injuries. Invited submission from the Joint Section Meeting On Disorders of the Spine and Peripheral.J Neurosurg Spine. 2006 Feb;4(2):118-22.

8. Bono CM, Vaccaro AR, Hurlbert RJ, Arnold P, Oner FC, Harrop $\mathrm{J}$, Anand N.Validating a newly proposed classification system for thoracolumbar spine trauma: looking to the future of the thoracolumbar injury classification and severity score. J Orthop Trauma 2006;20:567-72.

9. Denis F. The three column spine and its significance in the classification of acute thoracolumbar spinal injuries. Spine. 1983;8:817831.

10. Wood KB, Khanna G, Vaccaro AR, Arnold PM, Harris MB, Mehbod AA. Assessment of two thoracolumbar fracture classification systems as used by multiple surgeons. JBJS. 2005;87A:1423-1429.

11. Drew B, Bhandari M, Orr D, Reddy K, Dunlop RB.Surgical preference in anterior cervical discectomy: a national survey of Canadian spine surgeons.J Spinal Disord Tech. 2002;15:454-457.

12. Findlay JM, Grace MG, Saboe LA, Davis LA. A survey of vertebral burst-fracture management in Canada. Can J Surg. 1992; 35:407-413.

13. Glaser JA, Jaworski BA, Cuddy BG, Albert TJ, Hollowell JP, McLain RF, Bozzette SA. Variation in surgical opinion regarding management of selected cervical spine injuries. A preliminary study. Spine. 1998;23:975-983.

14. Irwin ZN, Hilibrand A, Gustavel M, McLain R, Shaffer W, Myers M, Glaser J, Hart RA.Variation in surgicaldecision making for degenerative spinal disorders. Part I: Lumbarspine. Spine. 2005;30:2208-2213.

15. Irwin ZN, Hilibrand A, Gustavel M, McLain R, Shaffer W, Myers M, Glaser J, Hart RA.Variation in surgical decision making 
for degenerative spinal disorders. Part II: Cervical spine. Spine. 2005;30:2214-2219.

16. Pickett GE, Van Soelen J, Duggal N. Controversies in cervical discectomy and fusion: practice patterns among Canadian surgeons. Can J Neurol Sci. 2004;31:478-483.

17. Furlan JC, Noonan V, Cadotte DW, Fehlings MG. Timing of decompressive surgery of spinal cord after traumatic spinal cord injury: an evidence-based examination of pre-clinical and clinical studies. J Neurotrauma. 2011 Aug;28(8):1371-99.

18. Rutges JP, Oner FC, Leenen LP. Timing of thoracic and lumbar fracture fixation in spinal injuries: a systematic review of neurological and clinical outcome. Eur Spine J. 2007 May;16(5):579-87.

19. Marr M, Hemmert K, Nguyen AH, Combs R, Annamalai A, Miller G, Pachter HL, Turner J, Rifkind K, Cohen SM. Team play in surgical education: a simulation-based study. J Surg Educ. 2012 Jan-Feb; 69(1):63-9.
20. Boszczyk BM, Mooij JJ, Schmitt N, Di Rocco C, Fakouri BB, Lindsay KW. Spine surgery training and competence of European neurosurgical trainees. ActaNeurochir (Wien). 2009 Jun; 151(6):619-28.

21. Wong K. Trauma education of junior hospital doctors at a major Australian trauma service. Surgeon. 2007 Apr; 5(2):76-80.

22. Lim MR, Vaccaro AR, Lee YJ, Zeieller SC, Jacoby S, SanFilippo J, Öner FC, Hulbert RJ, Fehlings IG, Arnold P, Harrop JS, Bono CM, Anderson PA, Anderson DG, Baron EM.The thoracolumbar injury severity scale and score (TLISS):inter-physician and inter-disciplinary validation of a newparadigm for the treatment of thoracolumbar spine trauma.COLUMNA.2006;5(3):157-164 . 2006;5(1):13-18

\title{
Da li je Thoracolumbar Injury Severity Score (TLISS) još uvijek dobra osnova za edukaciju specijalizanata ortopedije i traumatologije
}

\begin{abstract}
SAŽETAK
Uvod. Povrede torakolumbalne kičme koje su indikovane za hirurško liječenje potrebno je hirurški zbrinuti unutar 24 sata. Traumatolozi zaposleni u ustanovama koje nemaju spinalni odjel moraju biti u stanju da klasifikuju takvu povredu i da postave indikaciju za hirurško, odnosno neoperativno liječenje. Cilj ove studije je da utvrdi da li je Thoracolumbar Injury Severity Score (TLISS) još uvijek dobra osnova za klasifikaciju povreda torakolumbalne kičme i postavljanje pravilne indikacije za neoperativno, odnosno, hirurško liječenje.
\end{abstract}

Ispitanici i metode. Šest specijalizanata ortopedije i traumatologije iz Siene (Italija), pet specijalizanata ortopedije i traumatologije iz Kliničkog Centra Banja Luka (Bosna i Hercegovina) i pet specijalizanata ortopedije i traumatologije iz bolnice Alta Val d'Elsa, Siena (Italija) prezentovano je 24 klinička slučaja iz stručne literature gdje su prikazani sljedeći podaci: dob pacijenta, neurološki status pacijenta, opis povrede, mehanizam povrede i radiološki nalazi (RTG, MR). Navedena 24 pacijenta izabrani su iz literature po kriterijumu povreda koje najčešće viđa ortoped neiskusan sa problematikom traume kičmenog stuba (trauma niske energije, sa djelimičnim ili bez neuroloških ispada sa TLISS skorom 4). Specijalizanti iz tri navedene grupe trebali su da sve pacijente klasifikuju prema TLISS skoru i da odrede najprikladniji način liječenja - konzervativno ili hirurško, a zatim je vršeno poređenje klasifikacija i terapijskih odluka među navedenim grupama ljekara. Statistički metodi korišteni u ovoj studiji su: statistička značajnost, pouzdanost ( $\mathrm{P}<0.05)$, validnost odluke, procenat tačnosti i Kappa-Cohenov koeficijent.

Najbolji rezultati kod ocjenjivanja mehanizma povrede bili su u grupi ljekara Ortopedske bolnice sa tačnošću od 78,8\% $(P<0,05)$ i uz prosječnu korelaciju (K=0,598). Najbolji opis povrede predstavljen je od strane doktora iz Siene sa $87 \%$ tačnosti $(P<0,05)$ i korelaciju $(K=0,749)$. Doktori iz Siene dali su najbolju ocjenu neurološkog statusa sa $97,6 \%$ tačnosti $(P<0,05)$ i korelacijom (K=0,936). Procjena povrede PCL specijalizanata iz Siene bila je sa $64,7 \%$ tačnosti $(P<0,05)$ i sa korelacijom (K=0,426). Ukupan TLISS rezultat je najbolje izračunat od strane specijalizanata iz Siene sa $82 \%$ tačnosti $(P<0,05)$ i korelacijom $(K=0,718)$. Najadekvatniji izbor terapije imali su doktori iz Siene sa 80,3\% tačnosti $(P<0,05)$ i korelacijom $(K=0,707)$.

Zaključak. Trenutno su Denisova i AO klasifikacija najčešče korišćeni klasifikacijski algoritmi za prelome torakolumbalne kičme, ali su uočeni i određeni nedostaci u obje ove klasifikacije. Vrijednost TLISS ocijenjivana je od strane tri grupe specijalizanata kod prezentovana 24 pacijenta iz stručne literature. Značajne razlike u tačnosti pronađene su u određivanju stvarnog oštećenja kičmene moždine u nivou caude equine. Procjena integriteta zadnjeg longitudinalnog ligamenta (CLP) pomoću radiografije je niske tačnosti.

Ključne riječi: prelom kičme, torakolumbalna kičma, TLISS, edukacija 